\title{
Assessing the business case for environmental, social and corporate governance practices in South Africa
}

\begin{tabular}{|c|c|}
\hline \multicolumn{2}{|c|}{$\begin{array}{l}\text { Authors: } \\
\text { Ruth Johnson } 1 \text { (D) } \\
\text { Nadia Mans-Kemp }^{1} \\
\text { Pierre D. Erasmus }{ }^{1} \text { (D) }\end{array}$} \\
\hline \multicolumn{2}{|c|}{$\begin{array}{l}\text { Affiliations: } \\
{ }^{1} \text { Department of Business } \\
\text { Management, Faculty of } \\
\text { Economic and Management } \\
\text { Sciences, Stellenbosch } \\
\text { University, Stellenbosch, } \\
\text { South Africa }\end{array}$} \\
\hline \multicolumn{2}{|c|}{$\begin{array}{l}\text { Corresponding author: } \\
\text { Ruth Johnson, } \\
\text { rsolomons@sun.ac.za }\end{array}$} \\
\hline \multicolumn{2}{|c|}{$\begin{array}{l}\text { Dates: } \\
\text { Received: } 31 \text { July } 2018 \\
\text { Accepted: } 14 \text { Aug. } 2019 \\
\text { Published: } 28 \text { Nov. } 2019\end{array}$} \\
\hline \multicolumn{2}{|c|}{$\begin{array}{l}\text { How to cite this article: } \\
\text { Johnson, R., Mans-Kemp, N. \& } \\
\text { Erasmus, P.D., 2019, } \\
\text { 'Assessing the business case } \\
\text { for environmental, social and } \\
\text { corporate governance } \\
\text { practices in South Africa', } \\
\text { South African Journal of } \\
\text { Economic and Management } \\
\text { Sciences } 22(1) \text {, a2727. https:// } \\
\text { doi.org/10.4102/sajems. } \\
\text { v22i1.2727 }\end{array}$} \\
\hline \multicolumn{2}{|c|}{$\begin{array}{l}\text { Copyright: } \\
\text { ( 2019. The Authors. } \\
\text { Licensee: AOSIS. This work } \\
\text { is licensed under the } \\
\text { Creative Commons } \\
\text { Attribution License. }\end{array}$} \\
\hline \multicolumn{2}{|l|}{ Read online: } \\
\hline 回部品 & $\begin{array}{l}\text { Scan this QR } \\
\text { code with your } \\
\text { smart phone or } \\
\text { mobile device } \\
\text { to read online. }\end{array}$ \\
\hline
\end{tabular}

Background: By focusing on sustainable financial and environmental, social and corporate governance (ESG) returns, companies and investors can do well by doing good. Despite growing interest in sustainable corporate practices, limited ESG-related research has been conducted in South Africa. Previous researchers have mainly focused on corporate governance. All three ESG aspects should, however, be addressed to ensure corporate sustainability. It is possible that the consideration of a composite ESG measure can conceal varying levels of consistency in the individual aspects.

Aim: The main objective was to investigate the relationship between ESG and corporate financial performance (CFP) measures.

Setting: Firms listed on the Johannesburg Stock Exchange between 2011 and 2016. A total of 66 firms were considered from six sectors.

Methods: Data for the sample (359 firm-year observations) were analysed by conducting panel regressions. In line with international research, ESG was considered as the independent variable, while eight measures of CFP were individually considered as the dependent variables. Composite and individual ESG disclosure scores were obtained from Bloomberg. The respective accounting-based, market-based and value-based CFP measures were sourced from IRESS.

Results: Two main trends emerged from this study. The majority of the significant relationships identified between variables were only observed: (1) once the composite ESG disclosure score was disaggregated and (2) when a distinction was made among sectors.

Conclusion: The empirical evidence suggests that ESG aspects are not homogeneous across sectors. Firm leaders should hence employ a differentiated approach to address the most important risks relevant to their operating environments.

Keywords: Environmental practices; social considerations; corporate governance; ESG; disclosure; corporate financial performance; accounting-based; market-based; value-based.

\section{Introduction}

William Ford Junior (Ford Motor Company 2010) remarked that 'creating a strong business and building a better world are not conflicting goals; they are both essential ingredients for long-term success'. His quote underlines the importance for managers and directors to consider simultaneously pertinent sustainability issues while striving to build successful businesses. The concept of sustainability is of particular importance to investors who engage in responsible investing (RI) (Van Der Ahee \& Schulschenk 2013). Such investors incorporate environmental (E), social (S) and corporate governance $(G)$ aspects in addition to risk-and-return considerations when assessing investee firms (Pasquini-Descomps \& Sahut 2013). The inclusion of non-financial information in addition to corporate financial performance (CFP) broadens the scope of investment analysis and decision making (Bassen \& Kovács 2008; Eccles et al. 2007; Pasquini-Descomps \& Sahut 2013). Responsible investors acknowledge the potential positive and long-term impact of sound ESG risk management on CFP (Van Der Ahee \& Schulschenk 2013).

Previous research on the relationship between ESG and CFP was mainly conducted in the developed market context (Balatbat, Siew \& Carmichael 2012; Ferrero-Ferrero, FernándezIzquierdo \& Muñoz-Torres 2016; Nollet, Filis \& Mitrokostas 2016; Pasquini-Descomps \& Sahut 2013; Qiu, Shaukat \& Tharyan 2016; Velnampy \& Pratheepkanth 2013). Less research has been carried out on the ESG practices of companies doing business in developing and emerging 
markets (Aaltonen 2013; Sustainable Investment Research Analyst Network 2009). Based on a literature review, it was evident that researchers primarily used accounting-based (Chetty, Naidoo \& Seetharam 2015; De Klerk \& De Villiers 2012; Demetriades \& Auret 2014; Marcia, Maroun \& Callaghan 2015; Mutezo 2014) and non-risk-adjusted marketbased (Breuer \& Nau 2014; Chetty et al. 2015; Horn, De Klerk \& De Villiers 2018; Nkomani 2013) CFP measures, while ignoring the potential risk-reducing benefits that sound ESG practices could hold for emerging market firms.

In the current study, CFP was measured by employing accounting-based, market-based and value-based metrics. Accounting-based CFP measures focus on a firm's past performance (Cooper 2017; Margolis \& Walsh 2001). Critique against accounting-based measures includes the fact that such ratios may be manipulated by managers through changing accounting methods or accruals, that they can be influenced by inflation and that they may be difficult to interpret across sectors (Velnampy \& Pratheepkanth 2013; Venanzi 2012). Despite these concerns, the return on assets (ROA) and earnings per share (EPS) ratios are extensively used to measure accounting-based performance (Porter \& Norton 2016). The ROA profitability measure reflects how well a firm's management has used its total assets to generate profit for a given year. The EPS ratio reflects the amount of attributable earnings that were earned per ordinary share in a specific year (Els, Erasmus \& Viviers 2014).

Market-based CFP measures are typically based on the value of a company's ordinary shares. Such measures are used to reflect on expectations about future performance (Margolis \& Walsh 2001; Martin, Petty \& Wallace 2009). Furthermore, market-based measures are less subject to managerial manipulation than accounting-based metrics (Gentry \& Shen 2010). These measures are typically utilised by the potential investors of a firm (Masa'deh et al. 2015). Market-based methods can be affected by exogenous factors, such as the overall share market performance. The market-based measures that were used in this study are the earnings yield (EY) and total shareholder return (TSR) ratios. The EY ratio is a popular indication of value as it compares the EPS to the market price per share. The TSR measure considers the dividend income and the change in the share price over the investment horizon (Cooper 2017; Megginson, Smart \& Lucey 2010).

Value-based measures aim to remove the accounting distortions that are evident in a firm's financial statements and are often regarded as an improvement on the traditional performance measures (Erasmus 2008; Maditinos, Šević \& Theriou 2006). Such methods take the cost of capital into account in an attempt to determine a firm's potential to create value (Erasmus 2008). The return on invested capital (ROIC), the spread, market value added (MVA) and cash return on invested capital (CROIC) are examples of value-based measures, and are included in this study to assess shareholder wealth creation. The ROIC measure compares the net operating profit after tax (NOPAT) generated by a firm to the amount of the net operating capital (NOC) employed. The spread is utilised to consider the difference between a firm's ROIC and weighted average cost of capital (WACC). If the ROIC generated by a firm is larger than its WACC, growth is profitable and the firm is adding value (Brigham \& Daves 2010). The difference between the market value of a firm's shares and the equity capital supplied by investors is referred to as the MVA (Cooper 2017). In contrast to ROIC, the CROIC measure represents the amount of free cash flow (FCF) being generated in a firm in comparison to the NOC. None of the considered studies included value-based metrics. This exclusion indicates a gap in the literature, as these measures focus on the long-term sustainable value creation potential of a firm in a socially responsible context.

Despite the growing interest in sustainable corporate practices in emerging markets, limited ESG-related research has been conducted in South Africa. The majority of local researchers have focused on corporate governance (Mangena \& Chamisa 2008; Mans-Kemp, Erasmus \& Viviers 2017; Ntim et al. 2012; Tshipa et al. 2018; Waweru 2014). This tendency could be ascribed to the country's well-developed corporate governance framework provided by the King reports. The implementation of sound corporate governance practices is therefore often the first level of ESG integration for local firms. However, to ensure corporate sustainability, it is important for managers and directors to engage with all three ESG aspects (Linnenluecke \& Griffiths 2010).

Against this background, the authors investigated the business case for the ESG practices of selected Johannesburg Stock Exchange (JSE) listed companies between 2011 and 2016 by employing an assortment accounting-based, marketbased and value-based CFP measures. The results could enhance the understanding of ESG and motivate corporate managers and directors to allocate more time and financial resources to the consideration and active management of ESG risks. Unless more attention is given to sustainable longterm value creation, shareholders run the risk of benefiting over the short run, but experiencing severe negative consequences over the long term (Institute of Directors in Southern Africa [IoDSA] 2016).

The remainder of the article is structured as follows: a critical overview of the theoretical link between various sustainability-related terms is first offered. The local ESG context and pertinent ESG-related developments are also discussed, followed by an overview of previous research on the topic and the formulation of the hypotheses. Thereafter, the collection of quantitative ESG and CFP data for 66 JSElisted firms is explained. The resulting panel data set was analysed by means of panel regression analysis. Based on the reported results, recommendations are offered to relevant stakeholders.

\section{Literature review}

An explanation of several sustainability-related terms is offered which provides the theoretical background for the consideration of ESG aspects in South Africa. 


\section{Clarification of relevant terms}

Sustainability considers the effect of the current generation's actions on the ecosystems, societies and environments of the future (Ameer \& Othman 2012). Sustainability comprises social (people-related), economic (profit-related), environmental (planet-related) and cultural (diversity-related) components (Werbach 2009). A sustainable firm should aim to eliminate any potential negative impact pertaining to all four sustainability components.

The challenges faced by firms in the 21st century require a fundamental change in the way businesses function. Traditionally, firms and investors aimed to reach the 'ultimate investment goal', namely to maximise return given a certain level of risk (IoDSA 2011). However, challenges such as climate change, insufficient energy provision and the depletion of natural resources also require attention, since ESG aspects can have a considerable impact on the long-term sustainability of firms (Quinn \& Baltes 2007; Van Der Ahee \& Schulschenk 2013). A paradigm shift is therefore required in the way in which (some) corporate managers and investors make decisions and construct their investment portfolios.

In an attempt to address sustainability challenges, firms started to engage in corporate social responsibility (CSR) initiatives in the late 1990s (Carroll \& Shabana 2010; Nkomani 2013). CSR can be defined as:

... the social responsibility of a business which encompasses the economic, legal, ethical, and discretionary philanthropic expectations that society has of organisations at a given point in time. (Carroll 1999)

Furthermore, Matten and Moon (2008) highlighted that CSR consists of clearly articulated and communicated policies and programmes that reflect a company's responsibility for broader societal good. The concepts RI and CSR are closely linked. Whereas CSR focuses on wealth creation from the perspective of firms, RI considers wealth creation from the viewpoint of investors (Viviers, Krüger \& Venter 2012).

The term socially responsible investment (SRI) is essentially underpinned by ethical requirements to shape the market, while the RI concept integrates both ESG and financial aspects into mainstream investment decision-making (Van Der Ahee \& Schulschenk 2013). Since the launch of the United Nations Principles for Responsible Investment (UN PRI), more researchers and practitioners have been using the term 'responsible investing' rather than 'socially responsible investing' (Viviers et al. 2012).

The CSR concept could be considered as a building block for corporate social performance (CSP) (Carroll 1999). The term CSP reflects a comprehensive assessment of a firm's observable outcomes as it relates to socially responsible behaviour (Cooper 2017; Simpson \& Kohers 2002; Van Der Laan, Van Ees \& Van Wittelosstuijn 2008). The key motivation for firms to engage in CSR, while improving their CSP, is to contribute to an improved society at large (Carroll \& Shabana 2010). The definitions forboth CSR and CSP focus mainly on environmental and social considerations (Carroll \& Shabana 2010), while omitting corporate governance (Dahlsrud 2008). As responsible investors consider all three ESG aspects, the scope of their investment analysis is broadened by including corporate governance aspects in addition to CSR and CSP considerations (Eccles et al. 2007; Pasquini-Descomps \& Sahut 2013).

There are various misconceptions associated with the inclusion of ESG aspects in investment analysis and corporate decision-making. Some investors believe that the integration of ESG aspects would result in a high-risk investment with a low return (Eccles et al. 2007). However, this is not necessarily the case. When investing in a responsible manner, investors are encouraged to act as long-term shareholders and less like share traders. Active shareholders are expected to engage with investees on various ESG concerns (Eccles et al. 2007). The proper evaluation of a firm's ESG practices thus facilitates a better understanding of the risks and opportunities relevant to a firm (Bassen \& Kovács 2008; Gond et al. 2018). This could lead to improved investment decision-making. Losses associated with poor ESG performance could be avoided and the risk associated with an investment could be more accurately assessed.

\section{Environmental, social and corporate governance considerations in South Africa}

Environmental aspects that are of particular concern to companies operating in South Africa include climate change, a lack of water, the destruction of natural habitats, overfishing and pollution (Hebb et al. 2016). Climate change will most likely have an even greater effect on firms' operations, revenues and costs in future (Girdwood 2013). An improved understanding of these aspects would enable firms to address the effects thereof more efficiently. Responsible investors should also consider these concerns when establishing their environmental screening criteria (Hebb et al. 2016).

South Africa has a legacy of social injustices that have hampered its socio-economic development (Herringer, Firer \& Viviers 2009). Regulatory measures such as the Employment Equity Act (No. 55 of 1998) and the Broad-Based Black Economic Empowerment (B-BBEE) Act (No. 53 of 2003) have aimed at addressing the inequalities brought about by the apartheid system. Furthermore, the increasing number of individuals living with HIV and AIDS still places considerable pressure on the country's social and economic development. This disease results in several direct and indirect expenditures for companies, including increased absenteeism and decreased productivity as well as escalating healthcare and HIV / AIDS awareness training costs (Hebb et al. 2016).

In terms of governance issues, the country has a welldeveloped corporate governance framework. The latest King report (King IV) centres on value creation in a sustainable manner (IoDSA 2016). Key concepts highlighted in King IV include ethical leadership, sustainable development, corporate citizenship, stakeholder inclusivity, integrated thinking and 
integrated reporting (IoDSA 2016). There is an enhanced focus on sustainability matters in addition to financial performance.

An integrated report entails a combination of the traditional annual report, which focusses mainly on financial performance, and a separate sustainability report. Locally, integrated reporting is promoted by the Integrated Reporting Committee (IRC) of South Africa. One of the main objectives of this committee is to design, distribute and encourage standardised integrated reporting guidelines. An efficient integrated report should reflect the economic, social and environmental dimensions of a firm (IRC of South Africa 2018). Firms are encouraged to publish details related to the six capitals of their business models, including their financial, manufacturing, human, intellectual, natural and social and relationship capital (IoDSA 2016).

Traditionally, financial performance has mainly been the basis on which current and potential investors have conducted investment analysis and decision-making (Cooper 2017; IoDSA 2011, 2016). Sustainability-related risks relating to the other capital sources, however, pose a threat to the long-term value creation capacity of local companies. While South African investors have been slow to engage with the boards of investee firms on ESG aspects, they are gradually starting to acknowledge and integrate ESG aspects into their investment activities and decision-making (Viviers \& Smit 2015).

The increased interest in firms' ESG considerations stems particularly from the institutional investor community (Atkins \& Maroun 2012; Pasquini-Descomps \& Sahut 2013; Viviers \& Smit 2015). Given that South Africa is one of Africa's largest institutional investment markets, institutional investors play a critical role in influencing local corporate behaviour. They can encourage positive ESG-related reforms in the investment sector (IoDSA 2011). If RI is actively pursued by local investors, positive contributions can be made to socioeconomic development in South Africa (Viviers et al. 2009).

After the publication of the King III report in 2011, a recommendation was made that a separate report should be released, focusing on the expectations of institutional investors (IoDSA 2011). The Code for Responsible Investing in South Africa (CRISA) was released in 2011 to guide institutional investors on how to perform investment analysis and activities effectively. The code highlights that it is no longer appropriate for institutional investors to focus narrowly on the monetary benefits to beneficiaries. Attention should also be given to ESG aspects which could have an impact on long-term sustainability and value creation (IoDSA 2011).

Institutional investors have a fiduciary duty to act in the best interests of their beneficiaries (Hebb et al. 2016). Beneficiaries may, however, question whether ESG aspects are related to financial performance. Researchers differ on whether ESG aspects are associated with long-term financial performance and corporate sustainability, as explained next.

\section{Overview of previous studies and hypotheses development}

Based on a meta-analysis of 52 studies on ESG, CSR, CSP and CFP, Orlitzky, Schmidt and Rynes (2003) concluded that the majority of authors reported positive relationships across industries and study contexts. More than a decade later, Friede, Busch and Bassen (2015) also conducted a metaanalysis of 2200 studies and reported that approximately $90 \%$ indicated a positive or neutral association between ESG and CFP. Pertaining to abnormal returns, Revelli and Viviani (2015) reported that the inclusion of CSR in share portfolios is regarded as neither a weakness nor a strength compared with conventional investments. They based this observation on a meta-analysis of 85 studies and 190 experiments on the financial performance of SRI. The heterogeneous findings could be ascribed to the different thematic approaches, investment horizons and analyses (Revelli \& Viviani 2015).

Previous researchers employed a variety of accounting, market and value-based metrics, intended to gauge different aspects of CFP. While accounting-based CFP measures focus on a firm's past performance, market-based metrics could be used to reflect expectations about future performance. Valuebased measures account for the cost of capital when assessing a firm's value creation potential (Margolis \& Walsh 2001).

\section{The association between environmental, social and corporate governance disclosure and accounting-based corporate financial performance}

In a seminal study, Waddock and Graves (1997) considered the link between CSP and lagged ROA, return on equity (ROE) and return on sales (ROS) in the United States (US) in 1990. They constructed a CSP index by using KLD data. They argued that strong financial performance could result in resource allocation to improve CSP. As such, a virtuous circle is created where companies 'do well by doing good'. Rodriguez-Fernandez (2016) confirmed the existence of such a circle, based on a positive link between CSR and profitability for Spanish companies.

Callan and Thomas (2009) employed KLD CSP data and also noted a positive CSP-CFP relationship (ROA and ROS). Their findings imply that the benefits associated with investment in socially responsible practices outweigh the costs thereof. In addition, Ferrero-Ferrero et al. (2016) noted significant positive relationships between ESG performance (particularly social and environmental aspects) and the Thomson Reuters Datastream ASSET4 economic performance score for $15 \mathrm{EU}$ member states. Breuer and Nau (2014) reported a similar association in the US between Thomson Reuters Datastream ASSET4 ESG scores and ROA. Michelon, Boesso and Kumar (2013) concluded that if CSR initiatives are linked to stakeholder preferences, they have a larger effect on accounting-based CFP than other initiatives.

Some international authors also employed Bloomberg's ESG disclosure scores. Nollet et al. (2016) observed a U-shaped relationship between ESG and ROA for Standard 
and Poor's 500 companies between 2007 and 2011. They hence argued that expenditure pays off only after a threshold CSP has been reached. Governance was founded to be the key driver affecting the observed relationship. In addition, Qiu et al. (2016) noted a positive relationship between lagged profitability and Bloomberg's social disclosure score in the United Kingdom (UK) between 2005 and 2009. They concluded that companies with more economic resources make more extensive social disclosures which yield positive financial benefits compared to those of their less profitable counterparts.

Several local authors employed the JSE SRI Index as a proxy for CSR and SRI. Nkomani (2013) found that firms not included in the index performed better over the period 2002 to 2011 than constituent companies. He compiled a total return index, including the net profit margin, ROA and ROE to measure CFP. In addition, Mutezo (2014) reported insignificant positive associations between SRI and ROE and ROA, while a significant positive relationship was noted between EPS and SRI. In contrast, Demetriades and Auret (2014) reported that there seemed to be no causal relationship between CSR and CFP (ROA and ROE) between 1995 and 2009. Du Toit and Lekoloane (2018) also reported no significant associations between CSR and CFP (ROE and price earnings) between 2009 and 2014. Chetty et al. (2015), however, reported significant links at industry level between CSR and EPS, ROA and ROE between 2004 and 2013.

The majority of South African authors have focused on CSR that narrowly centres on the environmental and social aspects of a firm, but omits corporate governance. Given the complex nature of ESG, the usage of an aggregated index as a proxy for ESG or SRI is questionable. For the purpose of this study, Bloomberg's composite ESG, as well as the individual ESG disclosure scores, were thus employed. Given inconclusive evidence on the nature of the relationship between ESG and different accounting-based financial performance, two of the most commonly employed accounting-based CFP measures were incorporated for the purpose of this study. The following null hypothesis was formulated:

$H_{01}$ : There is no relationship between the ESG disclosure scores and the accounting-based CFP of selected JSE-listed firms from 2011 to 2016.

\section{The link between environmental, social and corporate governance disclosure and market-based corporate financial performance}

In the international context, Callan and Thomas (2009) reported a positive link between KLD's CSP and Tobin's Q. Similarly, Breuer and Nau (2014) noted that Thomson Reuters Datastream ASSET4 ESG scores were positively related to Tobin's Q in the US. In contrast, Horn et al. (2018) reported no significant association between CSR disclosure and Tobin's $Q$ for selected South African firms, although a significant negative relationship was noted with firm value. They argued that there is a link between CSR assurance and the need to enhance CSR reporting credibility. Since the relationship between Tobin's $Q$ and firm performance is confounded by endogeneity, other local authors excluded this measure (Mans-Kemp et al. 2017).

Lins, Servaes and Tamayo (2017) reported that US firms with high CSR intensity had higher share returns than those with low CSR during the 2008-2009 global financial crisis. Trust that is built between a firm and investors through investments in social capital seemingly paid off when the market suffered this considerable shock. Galema, Plantinga and Scholtens (2008) noted that SRI impacted on US share returns by lowering the book-to-market ratio and not by generating positive alphas. They explained that excess demand for the relatively small SRI stock universe predicates overpricing thereof. Applying Vigeo sustainability ratings, Van De Velde, Vermeir and Corten (2005) reported no significant outperformance of sustainability- rated portfolios before the crisis. Brammer, Brooks and Pavelin (2006) noted that socalled 'socially least desirable shares' had considerable abnormal returns in the UK. In addition, Balatbat et al. (2012) reported that the returns of so-called 'ESG leaders' in Australia were lower than those of 'ESG laggards'. They argued that ESG scores possibly 'do not inform sufficiently about the true sustainability practices that provide a flow-on effect to firm performance'.

Hörnmark (2015) considered selected US and sub-Saharan African companies and reported that ESG-integrated portfolios generated significant positive alphas in emerging markets. Viviers et al. (2008) considered risk-adjusted returns for local RI funds by employing the Sharpe, Sortino and upside-potential ratios. Their findings showed that local RI funds underperformed relative to their benchmark indices between June 1992 and March 2002, but significantly outperformed their benchmark indices between April 2002 and March 2006. They remarked that SRI has been acknowledged as an approach that can be implemented to manage ESG risks effectively.

Several local authors conducted event studies to estimate SRI portfolio performance. Demetriades and Auret (2014) employed the same risk-adjusted measures as Viviers et al. (2008) and revealed that none of the event dates under consideration had any influence on JSE SRI constituents' share prices. Gladysek and Chipeta (2012) investigated whether the announcement of SRI Index constituents (they regarded it as a CSR signal for investors) had an impact on share returns between 2004 and 2009. By applying the capital asset pricing model (CAPM), they reported that the index constituents did not outperform those included in the JSE All Share Index. In contrast, Chetty et al. (2015) noted that investors were rewarded in 2004 and 2012 when firms entered the JSE SRI Index.

Other authors applied the Ohlson model in the South African context. De Klerk and De Villiers (2012) found that JSE-listed firms with high levels of corporate responsibility reporting had high share prices. Such reporting provides information to shareholders that could affect their valuation of a company. 
The Ohlson model regards the market value of equity as a function of book value, accounting for earnings and other (non-accounting) value-relevant information. Marcia et al. (2015) also investigated the value relevance of corporate responsibility reporting of 82 JSE firms by applying this model. They reported no significant share price association and remarked that CSR disclosure does not per se add value to a firm's share price.

Several previous authors investigated the abnormal returns of ESG portfolios (proxied by the JSE SRI Index). In contrast, the authors of this study considered the market-based TSR and EY measures and employed Bloomberg's ESG disclosure scores. The following null hypothesis was formulated:

$H_{02}$ : There is no relationship between the ESG disclosure scores and the market-based CFP of selected JSE-listed firms from 2011 to 2016.

\section{The relationship between environmental, social and corporate governance disclosure and value-based corporate financial performance}

It is evident that previous international and local authors focused on accounting-based and market-based CFP measures. Exceptions include Balatbat et al. (2012), who incorporated ROIC in an Australian study, and Nollet et al. (2016), who examined the relationship between Bloomberg's ESG disclosure scores and return on capital for selected Standard \& Poor's 500 companies. A significant negative relationship was reported with CSP.

Given the paucity of research on the association between ESG disclosure and value-based CFP in corporate South Africa, the following null hypothesis was formulated:

$H_{03}$ : There is no relationship between the ESG disclosure scores and the value-based CFP of selected JSE-listed firms from 2011 to 2016.

\section{Research design and methodology}

To assess the business case for ESG practices in South Africa, a positivistic paradigm was adopted, which resulted in the collection and analysis of secondary quantitative data.

\section{Sample selection}

The population consisted of all JSE-listed firms for the period 2011 to 2016 (the King III regime). The start of the research period concurred with the advent of integrated reporting locally. A combination of convenience and judgement sampling was used to draw a sample of 66 companies from six JSE sectors. The convenience sampling technique was employed based on ease of collecting readily available standardised ESG and CFP data. The judgement criteria were as follows:

- A firm had to be listed on the JSE for at least two years (to ensure that there would be sufficient data points for statistical analysis).

- A firm's ESG disclosure score had to be available on the Bloomberg (2017) database.

- A firm's CFP data had to be available on the IRESS (2017) database.
ESG data were available for 373 firm-year observations, but the required financial data were available for only 359 firmyear observations. Firms operating in the consumer goods, consumer services, healthcare, technology, telecommunications and industrials sectors (hereafter referred to as the considered sectors) were examined. Firms listed in the basic materials and financials sectors were excluded from the sample as their annual financial statements, the nature of their activities and the level of regulation differ from those of the firms listed in the considered sectors. No companies were listed in the utilities sector during the research period.

\section{Environmental, social and corporate governance disclosure scores}

In line with international researchers (such as Breuer \& Nau 2014; Ferrero-Ferrero et al. 2016; Pasquini-Descomps \& Sahut 2013), ESG was considered as the independent variable in this study. The Bloomberg (2017) database provided standardised composite and individual ESG disclosure scores for the considered JSE-listed companies. The database gathers ESG data from publicly disclosed corporate sources such as CSR reports, integrated reports and company websites. In some instances, proprietary surveys are also conducted by Bloomberg to request specific information. The Bloomberg (2017) ESG categories are indicated in Table 1.

\section{Corporate financial performance measures}

Table 2 summarises the CFP variables that were used, consisting of accounting-based, market-based and valuebased metrics.

In line with Breuer and Nau (2014), Ferrero-Ferrero et al. (2016), Pasquini-Descomps and Sahut (2013) and Balatbat et al. (2012), the authors controlled for firm size and leverage. It is likely that smaller firms will not have the same level of ESG consideration as larger firms, mostly because of financial reasons. As firms become larger, it is expected that they will receive more attention from various external stakeholders. In the same way, large firms will have a tendency to respond to diverse stakeholders' demands (Breuer \& Nau 2014; Waddock \& Graves 1997). Market capitalisation data were sourced from IRESS and used as a proxy for firm size. Management's attitude towards risk could have a direct impact on CFP, resulting from decisions relating to cost management and investment opportunities (Breuer \& Nau 2014; Waddock \& Graves 1997). The debt-to-assets ratio can be utilised as a proxy for management's risk tolerance (Breuer \& Nau 2014). This leverage ratio was sourced from IRESS. The researchers also controlled for industry, as companies operating in six JSE sectors were considered.

\section{Data analysis}

Descriptive statistics were computed to evaluate trends in the data set. Pooled ordinary least squares (OLS) and fixed effects 
TABLE 1: Bloomberg's environmental, social and corporate governance considerations.

\begin{tabular}{lll}
\hline Environmental aspects & Social aspects & Corporate governance aspects \\
\hline Risks created by operational decisions & Risks arising from human resources policies and practices & Risks stemming from flaws in corporate governance policies \\
Carbon emissions & Supply chains & Voting practices \\
Climate change & Discrimination & Executive compensation \\
Pollution & Political contributions & Shareholders' rights \\
Waste disposal & Diversity & Takeover defences \\
Renewable energy & Human rights & Staggered boards (election of board members) \\
Resource depletion & Community relations & Independent directors \\
\hline
\end{tabular}

Source: Based on data provided by Bloomberg L.P., 2017, ESG disclosure scores, Research domain, Software and database, New York.

TABLE 2: Measurement of the selected corporate financial performance variables.

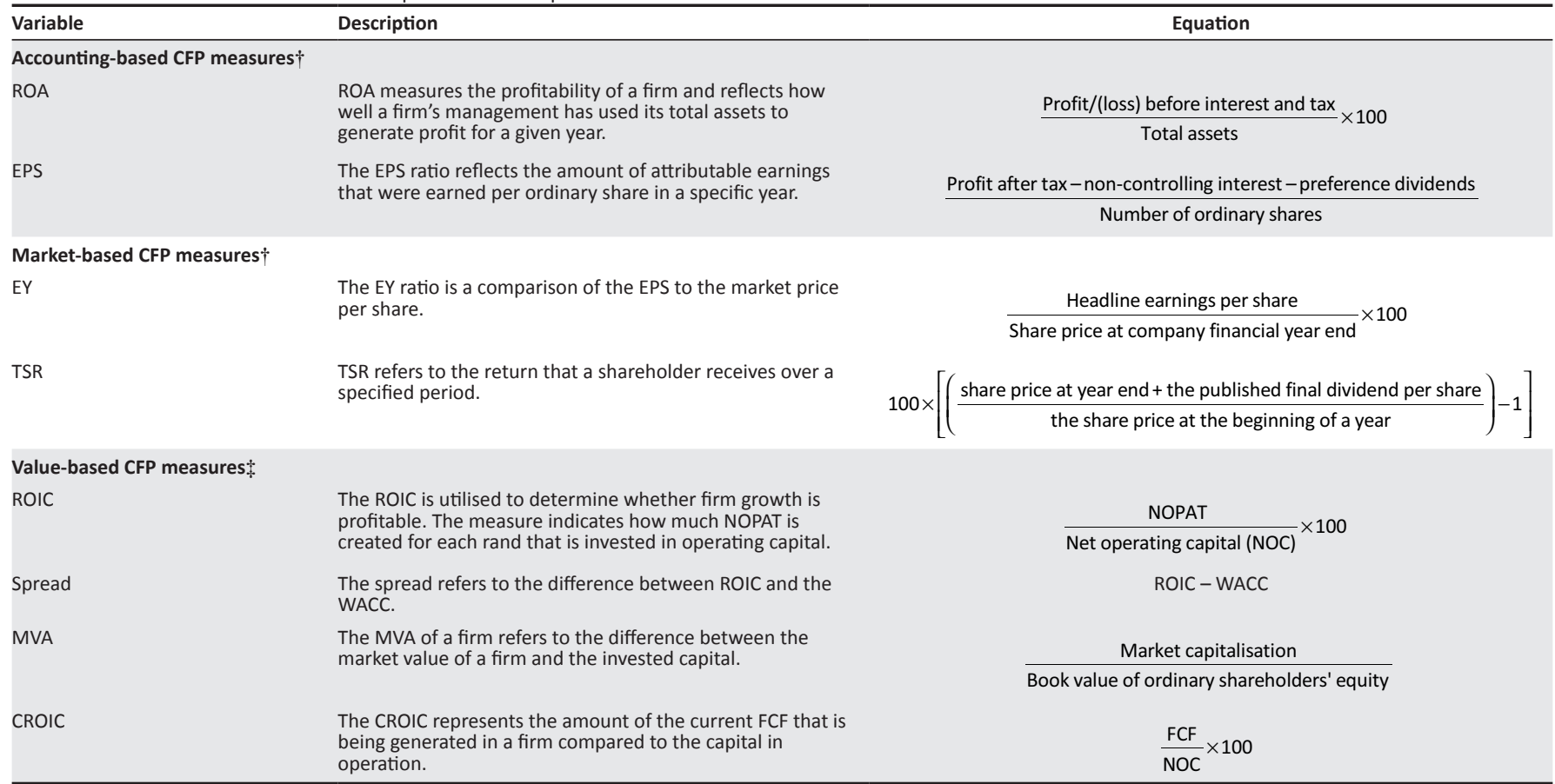

$\dagger$, Sourced from IRESS (2017); $\uparrow$, Calculated by the researchers based on data sourced from IRESS (2017).

CFP, corporate financial performance; ROA, Return on assets; EPS, Earnings per share; EY, Earnings yield; TSR, Total shareholder return; ROIC, Return on invested capital; MVA, Market value added; CROIC, Cash return on invested capital; FCF, Free cash flow; WACC, Weighted average cost of capital; NOPAT, net operating profit after tax.

and random effects panel regression analyses were conducted to investigate the relationship between the dependent and the independent variables. To select the appropriate regression models, the $F$-test for fixed effects and the Hausman-test were used. Panel regression analyses were conducted on the composite ESG, as well as individual ESG disclosure scores.

Specification errors may occur when conducting regression analysis, including heteroskedasticity and multicollinearity. Acceptable tolerance values were reported and the results were adjusted for heteroskedasticity where applicable. Pertaining to reliability, the reported observations are not generalisable to all JSE-listed firms, as some sectors were excluded. The study can be reproduced in future by using a similar methodology. When considering validity, it should be taken into account that the ESG scores as reported by Bloomberg (2017) were used. Firms' actual ESG performance could, however, deviate from their disclosed performance. Ethical clearance was granted by the humanities research ethics committee at the researchers' university.

\section{Ethical consideration}

Ethical clearance was obtained for this study: SU-HSD-004264.

\section{Results and discussion}

Figure 1 provides a comparison of the trends identified in the mean scores of the composite ESG and individual ESG disclosure scores. The figure furthermore illustrates how changes in the individual components contributed to the change in the composite ESG disclosure score over the study period.

Environmental practices were the least disclosed ESG aspect over the research period as depicted in Figure 1. Resource depletion and the effects of climate change are some of the prominent environmental realities that leaders of JSE-listed firms should consider to ensure corporate sustainability (Hebb et al. 2016). However, based on the low, almost stagnant environmental disclosure scores (E-scores), it seems as if the considered companies gave limited attention to the disclosure of environmental aspects.

In contrast, the social disclosure score (S-score) displayed an increasing trend over the research period. Given the socioeconomic context of the country, it was expected that social aspects such as B-BBEE, poverty and HIV and AIDS policies would receive considerable attention from JSE-listed companies. 
Despite the increase, mean S-scores remained relatively low. In a study conducted by Van Der Ahee and Schulschenk (2013), institutional investors were questioned on the level of importance they had placed on ESG components. The results revealed that environmental and social aspects were viewed as 'less important' than corporate governance aspects.

South Africa offers a well-developed corporate governance framework to listed companies. The relatively high corporate governance disclosure score (G-score), in comparison to the E-score and S-score in Figure 1, could, however, also be partly attributed to the surge in corruption cases in South Africa. Van Der Ahee and Schulschenk (2013) and the World Economic Forum (2017) highlighted corruption as a prominent challenge for South African companies.

When comparing the individual ESG disclosure scores to the composite ESG disclosure score, it is evident that the E-scores and S-scores mostly contributed to the increase in the composite ESG disclosure score over time. The G-score remained relatively stable over the study period, thus providing a smaller contribution to the overall increasing trend of the composite ESG disclosure score. Despite the gradual increase, the composite ESG disclosures remained below 35 (out of 100).

\section{Regression analyses results for the sample}

Regression analyses were conducted on the composite ESG disclosure score as the independent variable and the

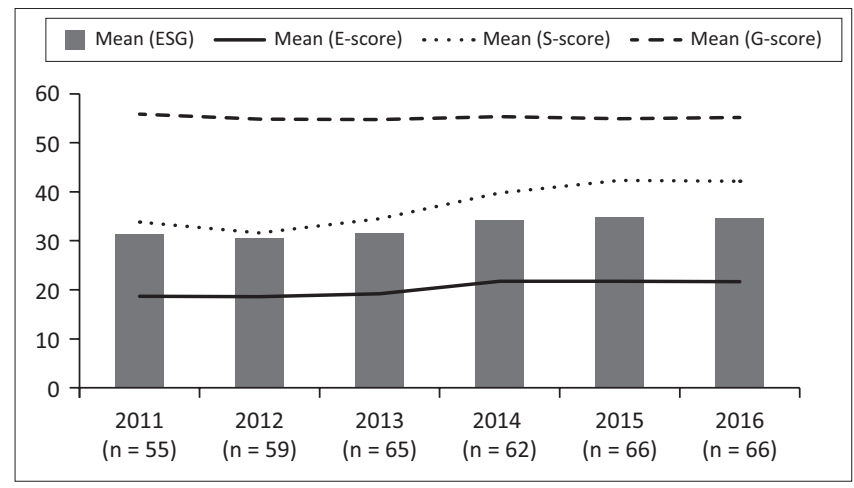

FIGURE 1: Annual mean values for the composite and individual environmental, social and corporate governance disclosure scores. respective CFP measures of the sample firms. No significant ESG regression coefficients were reported (refer to Panel A in Table 3). In contrast, Ferrero-Ferrero et al. (2016) found a significant positive relationship between the level of ESG performance and economic performance for selected companies in the European Union. According to them, it is possible that a composite ESG disclosure score can 'conceal different levels of uniformity in the ESG dimensions'. Limkriangkrai, Koh and Durand (2017) confirmed that firms engage with the individual ESG aspects to varying degrees. As such, the relationships between the individual ESG disclosure scores and CFP measures were also investigated (see Panel B in Table 3).

While no significant relationship was noted between the composite ESG disclosure score and accounting-based EPS, statistically significant E-score and S-score regression coefficients are reported in Panel B of Table 3 for EPS. These conflicting results highlight the importance of investigating the individual ESG aspects, rather than focusing only on the composite ESG disclosure score. Based on the statistically significant negative association between the E- score and accounting-based EPS, it can be inferred that firms with high E- scores reported lower attributable EPS in a specific year. The costs required to incorporate sound environmental initiatives could have a negative effect on the earnings realised by a firm, offering a potential explanation for the observed negative relationship.

In contrast, firms that disclosed more details on their social considerations generated higher accounting-based earnings. In line with this finding, Chetty et al. (2015) also noted a significant positive relationship between CSR and EPS in South Africa. As mentioned in the literature review, CSR mainly focuses on the environmental and social dimensions of ESG. Balatbat et al. (2012) similarly reported a statistically significant positive association between social aspects and economic performance for listed Australian firms.

A statistically significant negative regression coefficient is reported for the S- score and market-based TSR in Panel B of Table 3. This result suggests that those firms with higher S-scores generated lower market-based returns for shareholders. According to Richardson and Welker (2001),

TABLE 3: Summarised regression results for the sample companies.

\begin{tabular}{|c|c|c|c|c|c|c|c|c|c|c|}
\hline \multirow[t]{2}{*}{ Panel } & \multirow[t]{2}{*}{ Preferred model $\uparrow$} & \multirow{2}{*}{$\begin{array}{l}\text { Return on } \\
\text { assets: } \\
\text { Two-way } \\
\text { fixed effects }\end{array}$} & \multirow{2}{*}{$\begin{array}{l}\text { Earnings } \\
\text { per share: } \\
\text { One-way } \\
\text { fixed effects }\end{array}$} & \multirow{2}{*}{$\begin{array}{c}\text { Earnings } \\
\text { yield: } \\
\text { Two-way } \\
\text { fixed effects: }\end{array}$} & \multirow{2}{*}{$\begin{array}{c}\text { Total shareholder } \\
\text { return: Pooled } \\
\text { ordinary least } \\
\text { squares }\end{array}$} & \multicolumn{2}{|c|}{ Return on invested capital } & \multirow{2}{*}{$\begin{array}{l}\text { Cash return on } \\
\text { invested capital: } \\
\text { One-way fixed } \\
\text { effects }\end{array}$} & \multirow{2}{*}{$\begin{array}{c}\text { Market } \\
\text { value added: } \\
\text { Two-way fixed } \\
\text { effects }\end{array}$} & \multirow{2}{*}{$\begin{array}{c}\text { Spread: } \\
\text { Two-way } \\
\text { fixed effects }\end{array}$} \\
\hline & & & & & & $\begin{array}{l}\text { One-way } \\
\text { fixed effects }\end{array}$ & $\begin{array}{l}\text { Two-way } \\
\text { fixed effects }\end{array}$ & & & \\
\hline \multirow[t]{3}{*}{ Panel A } & Composite ESG & -0.03 & 0.93 & 0.02 & -0.19 & - & -0.12 & -0.18 & 2.41 & -0.06 \\
\hline & Leverage & $-20.15 * *$ & -119.12 & -3.94 & -5.71 & - & $-31.31 * *$ & $-64.31 * *$ & -9.52 & $-28.85 * *$ \\
\hline & Size & $12.13 * *$ & $468.04 * *$ & -0.04 & $3.10 *$ & - & $13.82 * *$ & -6.96 & $277.62 * *$ & $12.58 * *$ \\
\hline \multirow[t]{4}{*}{ Panel B } & E-score & -0.03 & $-5.04 * *$ & -0.03 & 0.20 & -0.01 & - & -0.05 & -0.62 & -0.04 \\
\hline & G-score & 0.01 & 3.75 & 0.01 & 0.10 & -0.04 & - & -0.02 & 2.90 & -0.04 \\
\hline & Leverage & $-20.10 * *$ & -108.21 & -3.54 & -8.67 & $-34.28 * *$ & - & $64.67 * *$ & 11.24 & $-28.51 * *$ \\
\hline & Size & $12.07 * *$ & $454.14 * *$ & 0.21 & $3.00 *$ & $8.15 * *$ & - & -7.04 & $269.09 * *$ & $12.84 * *$ \\
\hline
\end{tabular}

Note: Values in bold represents significant findings.

$\dagger$, The quality of fit of the preferred regression models were significant; $\downarrow$, The fit of the model for the earnings yield measure was insignificant.

*, significant at a 0.05 level; **, significant at a 0.01 level. 
a possible explanation for this negative relationship is that socially responsible investments made by firms are consistently negative net present value projects that contribute to overall risk. Although proponents of responsible corporate behaviour highlight the potential cost savings and long-term strategic advantages of CSR, the market could hold a different view. This negative relationship might therefore be partly ascribed to market participants perceiving the spending on social projects as superfluous.

Attention was also given to associations between the individual ESG disclosure scores and the CFP measures at the sector level. Only three of the six considered sectors, namely the consumer goods, consumer services and industrials sectors, had sufficient data to conduct regression analyses.

\section{Regression analyses results for the considered sectors}

Differentiation in the consideration of ESG aspects could be apparent for firms operating in different sectors. For example, a firm might engage in environmentally friendly activities, but could regard social responsibility aspects as less important, given that the firm's operations rely heavily on preventing environmentally damaging production processes.

All sector regression analyses were conducted with the individual ESG disclosure scores as the independent variables, and the respective CFP measures as the dependent variable.

\section{Consumer goods sector}

The results of the regression analyses conducted for the consumer goods sector are reported in Table 4.

A statistically significant positive relationship is observed between G-score and ROA in Table 4. This positive association reflects that consumer goods firms with high G-scores also reported high accounting-based ROA ratios. As such, bettergoverned consumer goods firms were more effective over the research period at utilising their assets to generate income than their poorly governed counterparts.

Similar to the results reported for the overall sample in Table 3, a significant negative relationship was observed between E-score and accounting-based EPS, while a significant positive relationship was reported between the S-score and accounting-based EPS for the consumer goods sector in Table 4. Therefore, the higher the S-score for a sample firm listed in this sector, the higher the reported accounting-based earnings by the firm. A negative regression coefficient is furthermore observed between the E-score and market-based EY. If an increase in the disclosure of environmental practices has a negative relationship with the EPS of a firm, it is likely also to result in a negative association with the EY ratio.

In addition, significant positive regression coefficients are observed between the G-score and the value-based ROIC and MVA measures in Table 4. Based on this finding, it can be deduced that those firms that had sound corporate governance practices in place tended to have higher returns on invested capital and an increased capacity to create aggregated shareholder value, in comparison to their counterparts, which lacked sound corporate governance.

\section{Consumer services sector}

The regression analyses results for the consumer services companies are reported in Table 5.

Similar to the findings reported in Table 4 for the consumer goods companies, Table 5 shows a statistically significant positive regression coefficient between the S-score and accounting-based EPS. In addition, a significant positive market-based EY ratio is also noted. These results suggest that consumer services firms with high S-scores generated high accounting-based earnings and market-based EY. Given the nature of this industry, it is understandable that aspects related to, among others, community relations, human rights, diversity and consumer protection would have an important role to play in the manner in which these firms conduct their business and their capacity to generate earnings.

A significant positive regression coefficient is furthermore reported between the S-score and the spread in Table 5. As such, it can be inferred that the considered consumer services firms that performed better in disclosing their social considerations earned higher returns in excess of their cost of capital. Such firms could be benefiting from a lower cost of debt or equity capital. The majority of global banks, including a few South African banks, are signatories to various voluntary principles, such as the Equator Principles, which require them to assess and manage environmental and social risks in project

TABLE 4: Regression results for the individual environmental, social and corporate governance disclosure scores for the consumer goods sector.

\begin{tabular}{|c|c|c|c|c|c|c|c|c|}
\hline Preferred model $\dagger$ & $\begin{array}{l}\text { Return on } \\
\text { assets: One-way } \\
\text { fixed effects }\end{array}$ & $\begin{array}{l}\text { Earnings per } \\
\text { share: One-way } \\
\text { fixed effects }\end{array}$ & $\begin{array}{c}\text { Earnings } \\
\text { yield: One-way } \\
\text { random effects }\end{array}$ & $\begin{array}{c}\text { Total shareholder } \\
\text { return: Pooled } \\
\text { ordinary least } \\
\text { squares: }\end{array}$ & $\begin{array}{l}\text { Return on invested } \\
\text { capital: One-way } \\
\text { random effects }\end{array}$ & $\begin{array}{l}\text { Cash return on } \\
\text { invested capital: } \\
\text { Two-way fixed } \\
\text { effects }\end{array}$ & $\begin{array}{l}\text { Market value } \\
\text { added: One-way } \\
\text { random effects }\end{array}$ & $\begin{array}{l}\text { Spread: One-way } \\
\text { fixed effects }\end{array}$ \\
\hline E-score & -0.18 & $-12.83^{*}$ & $-0.09 *$ & -0.14 & -0.26 & -0.42 & -1.89 & -0.24 \\
\hline S-score & 0.00 & $7.17 *$ & 0.05 & -0.08 & 0.02 & -0.25 & 1.34 & 0.02 \\
\hline G-score & $0.33 * *$ & -0.54 & -0.07 & 0.15 & $0.47 * *$ & 0.13 & $6.52 * *$ & 0.30 \\
\hline Leverage & $-15.74 * *$ & -8.03 & 1.50 & -4.01 & -11.59 & $-61.24 * *$ & $-240.58 * *$ & $-15.15 * *$ \\
\hline Size & 6.43 & $810.75^{* *}$ & $-2.48 *$ & 7.51 & 6.29 & 9.90 & $349.63 * *$ & 8.43 \\
\hline
\end{tabular}

Note: Values in bold represents significant findings.

$\dagger$, The quality of fit of the preferred regression models were significant; $\downarrow$, The fit of the model for the total shareholder return measure was insignificant.

*, significant at a 0.05 level; **, significant at a 0.01 level. 
TABLE 5: Regression results for the individual environmental, social and corporate governance disclosure scores for the consumer services sector.

\begin{tabular}{|c|c|c|c|c|c|c|c|c|}
\hline $\begin{array}{l}\text { Preferred } \\
\text { model } \dagger\end{array}$ & $\begin{array}{l}\text { Return on assets: } \\
\text { Two-way fixed } \\
\text { effects }\end{array}$ & $\begin{array}{l}\text { Earnings per share: } \\
\text { One-way random } \\
\text { effects }\end{array}$ & $\begin{array}{l}\text { Earnings yield: } \\
\text { One-way random } \\
\text { effects }\end{array}$ & $\begin{array}{c}\text { Total shareholder } \\
\text { return: Pooled } \\
\text { ordinary least } \\
\text { squares: }\end{array}$ & $\begin{array}{l}\text { Return on invested } \\
\text { capital: One-way } \\
\text { random effects }\end{array}$ & $\begin{array}{l}\text { Cash return on } \\
\text { invested capital: } \\
\text { One-way fixed } \\
\text { effects }\end{array}$ & $\begin{array}{l}\text { Market value added: } \\
\text { Two-way fixed } \\
\text { effects }\end{array}$ & $\begin{array}{l}\text { SPREAD: } \\
\text { Two-way fixed } \\
\text { effects }\end{array}$ \\
\hline E-score & -0.04 & -2.50 & -0.02 & 0.42 & 0.00 & -0.03 & 1.64 & -0.06 \\
\hline S-score & 0.02 & $3.41 * *$ & $0.05 * *$ & -0.32 & 0.01 & -0.02 & 0.70 & $0.10 \%$ \\
\hline G-score & -0.03 & 2.09 & 0.00 & 0.18 & $-0.45 * *$ & $-0.78 *$ & $8.10 *$ & -0.16 \\
\hline Leverage & $-12.55^{* *}$ & -38.89 & -1.34 & -8.17 & $-22.42 *$ & $-87.55 * *$ & -79.90 & $-24.61 * *$ \\
\hline
\end{tabular}

Note: Values in bold represents significant findings.

$\dagger$, The quality of fit of the preferred regression models were significant; $\uparrow$, The fit of the model for the total shareholder return measure was insignificant.

*, significant at a 0.05 level; **, significant at a 0.01 level.

TABLE 6: Regression results for the individual environmental, social and corporate governance disclosure scores for the industrials sector.

\begin{tabular}{|c|c|c|c|c|c|c|c|c|}
\hline $\begin{array}{l}\text { Preferred } \\
\text { model } \dagger\end{array}$ & $\begin{array}{l}\text { Return on assets: } \\
\text { Two-way fixed } \\
\text { effects }\end{array}$ & $\begin{array}{l}\text { Earnings per share: } \\
\text { Two-way fixed } \\
\text { effects }\end{array}$ & $\begin{array}{l}\text { Earnings yield: } \\
\text { Two-way fixed } \\
\text { effects }\end{array}$ & $\begin{array}{c}\text { Total shareholder } \\
\text { return: Pooled } \\
\text { ordinary least } \\
\text { squares }\end{array}$ & $\begin{array}{l}\text { Return on invested } \\
\text { capital: One-way } \\
\text { random effects. }\end{array}$ & $\begin{array}{c}\text { Cash return on } \\
\text { invested capital: } \\
\text { Pooled ordinary } \\
\text { least squares }\end{array}$ & $\begin{array}{l}\text { Market value added: } \\
\text { Two-way fixed } \\
\text { effects }\end{array}$ & $\begin{array}{c}\text { Spread: } \\
\text { One-way } \\
\text { random effects: }\end{array}$ \\
\hline E-score & 0.07 & -3.27 & -0.05 & -0.23 & -0.27 & $-0.50 * *$ & 0.05 & -0.25 \\
\hline S-score & 0.02 & 0.59 & -0.01 & $-0.42 *$ & 0.02 & $0.46 * *$ & -0.05 & -0.04 \\
\hline G-score & -0.03 & $5.35 \%$ & 0.05 & 0.29 & 0.11 & $0.47 *$ & -0.07 & 0.08 \\
\hline Leverage & $-27.89 * *$ & -287.59 & 12.48 & $-57.60 *$ & $-26.46 * *$ & -5.00 & -3.83 & $-23.17 *$ \\
\hline Size & 12.04 & 115.15 & $-22.45 *$ & -6.51 & $-4.89 * *$ & $-4.77 * *$ & $130.40 * *$ & -2.13 \\
\hline
\end{tabular}

Note: Values in bold represents significant findings.

$\dagger$, The quality of fit of the preferred regression models were significant; $\downarrow$, The fit of the model for the total shareholder return measure was insignificant.

*, significant at a 0.05 level; **, significant at a 0.01 level.

financing (Equator Principles 2018; Marco 2011). As a result, firms that are effectively disclosing their social considerations might be receiving a lower cost of debt when borrowing funds. Similarly, responsible investors are particularly interested in firms that perform well in disclosing social aspects and as such might have a lower required rate of return.

Based on the significant negative regression coefficients reported between the G-score and value-based ROIC and CROIC (Table 5), it seems as if the considered consumer services firms with higher G-scores generated lower ROIC and CROIC than those firms with lower G-scores over the study period. Corporate governance compliance is often costly for firms (Mans-Kemp et al. 2017). These costs relate to the implementation of corporate governance practices such as costs of compliance, opportunity, disclosure and reputational costs (Aguilera et al. 2008). The additional expenses incurred to comply with corporate governance standards could be a possible reason for the negative relationship observed for ROIC and CROIC. The higher the costs a firm incurs to implement initiatives and disclose information related to corporate governance practices, the lower the NOPAT and consequently also the FCF generated by the firm. A decrease in these values, by implication, would result in lower value-based ROIC and CROIC values.

When investigating the relationship between the individual ESG disclosure scores and firms' ability to create long-term shareholder value (MVA), a significant positive regression coefficient is reported for the G-score in both Tables 4 and 5 . The considered consumer goods and consumer services firms that were better governed therefore appear to have an improved ability to create sustainable shareholder wealth over the lifetime of the firm.

\section{Industrials sector}

The regression results for the industrials sector are reported in Table 6.

Table 6 depicts a significant positive regression coefficient between G-score and accounting-based EPS. Based on this finding, it can be deduced that well-governed industrial firms reported higher accounting-based earnings than those firms characterised by poor corporate governance practices. This outcome is in line with Mans-Kemp et al. (2017), who found a statistically significant positive association between corporate governance and EPS for a sample of JSE-listed companies that included several industrial firms for the period 2002 to 2010 .

A statistically significant negative regression coefficient is reported between the E-score and the value-based CROIC in Table 6. This finding implies that industrial firms with high E-scores yielded low CROIC values. In contrast, significant positive regression coefficients were reported for the S-score and G-score and CROIC. It can hence be inferred that industrial firms that provided a detailed disclosure of their social and corporate governance practices had high valuebased CROIC values. According to Bauer, Guenster and Otten (2004), sound corporate governance practices lead to higher investor trust. As investors view well-governed firms as less risky, they may require a lower expected rate of return, resulting in a higher firm value. Furthermore, well-governed firms may have high operating performance and therefore high expected future FCFs, which in turn, may lead to higher firm value over the long term (Breuer \& Nau 2014).

In Table 7, the research hypotheses are linked to the most significant outcomes of the statistical analyses. 
TABLE 7: Summary of the most significant outcomes of the statistical analyses.

Hypothesis
$\mathrm{H}_{00}:$ There is no relationship between
the ESG disclosure scores and the
accounting-based CFP of selected
JSE-listed firms from 2011 to 2016 .
$\mathrm{H}_{02}:$ There is no relationship between
the ESG disclosure scores and the
market-based CFP of selected JSE-
listed firms from 2011 to 2016 .
$\mathrm{H}_{03}:$ There is no relationship between
the ESG disclosure scores and the
value-based CFP of selected JSE-listed
firms from 2011 to 2016 .
Outcome

Reject $\mathrm{H}_{01}$ : A significant negative relationship was identified between the E-scores and EPS for the overall sample, as well as the consumer Reject $\mathrm{H}_{01}$ : A significant negative relationship was identified between the E-scores and EPS for the overall sample, as well as the consumer
goods sector. In contrast, a significant positive association was observed between the S-scores and EPS for the overall sample, as well as for the consumer goods and consumer services sectors. Pertaining to the G-scores and ROA, a significant positive link was noted for the considered consumer goods firms. A significant positive relationship was also established between the G-scores and EPS for the considered industrials firms.

Reject $\mathrm{H}$ : A significant negative relationship was established between the S-scores and TSR for the overall sample, as well as the considered industrial firms. A significant negative association was observed between the E-scores and $\mathrm{EY}$ for the considered consumer goods firms. Furthermore, a significant positive association was found between the S-scores and EY for the considered consumer services firms.

Reject $\mathrm{H}_{0}$ : A significant negative relationship was established between the E-scores and CROIC for the considered industrial firms. Significant positive associations were noted for the S-scores and G-scores and CROIC for the considered industrial firms. For the considered Significant positive associations were noted for the S-scores and G-scores and CROIC for the considered industrial firms. For the consid consumer goods firms, a significant positive relationship was found between the G-score and ROIC. In addition, a significant positive
association was established between the G-scores and MVA for the considered consumer goods and consumer services firms. Significant negative relationships were observed between the G-scores and ROIC and CROIC for the considered consumer services firms. Finally, a negative relationships were observed between the G-scores and ROIC and CROIC for the considered consumer services firms. Finally, a
statistically significant positive association was found between the S-scores and the spread for the considered consumer services firms.

CFP, corporate financial performance; CROIC, cash return on invested capital; CROIC, cash return on invested capital; EY, earnings yield; ROA, return on assets; EPS, earnings per share; TSR, total shareholder return; MVA, market value added.

As can be seen in Table 7, the researchers rejected all three of the formulated null hypotheses. When considering the relationship between the composite ESG disclosure score and the employed CFP measures, no significant relationships were observed. However, when distinguishing between the individual ESG components, significant results were reported for the sampled companies. It therefore seems that the composite ESG disclosure score failed to reflect the differences in ESG performance. When a further distinction was made between the individual ESG components at sector level, several significant results were reported. It is hence essential to consider the individual ESG aspects most applicable to a specific sector in addition to a range of CFP measures when considering the relationship between ESG and CFP.

\section{Conclusions, limitations and recommendations}

Sustainability-related challenges will continue to threaten the longevity of firms and society as the competition for resources constantly intensifies. As a result, it has now become more important than ever that firms acknowledge corporate sustainability challenges and actively manage their ESG risks. Previous authors mainly employed accounting-based and market-based performance measures when they considered the relationship between sustainability-related aspects (mostly CSR and SRI) and CFP in South Africa.

The business case for ESG practices in South Africa was assessed by focusing on a sample of JSE-listed firms operating across six different sectors, during a period subsequent to the advent of integrated reporting. This study could be considered novel as the authors included comprehensive composite ESG and individual ESG disclosure scores. In addition, a variety of CFP measures that also incorporated a set of value-based metrics not only expanded upon previous studies, but also ensured that the complex nature of financial performance is being recognised. The study hence addresses a gap in the existing body of knowledge on ESG and CFP in the emerging market context.

Based on the reported results, it is evident that ESG risks are not homogeneous across sectors and, as such, corporate leaders should employ a differentiated approach to address the most important risks relevant to their operating environments. Corporate managers need to acknowledge that ESG considerations are a combination of diverse aspects. To generate sustainable returns, it is important for corporate managers to embrace a long-term focus when dealing with ESG aspects. Directors could include ESG indicators to assess the competencies of management and the successful implementation of risk management mechanisms. Shareholders should furthermore engage more actively with firms on ESG concerns. Given their scope of influence, institutional investors should deliberately implement the recommendations and guidance provided by CRISA and the King IV report when engaging with investee firms.

The study's sample included firms from only six JSE sectors. Two sectors, namely the basic materials and financials sectors, that are essential in the local economy were omitted, given the nature of their primary activities and reporting. Future researchers could investigate the relationship between ESG and CFP in these sectors. In addition, it could be argued that investments in ESG initiatives by firms realise returns only over a longer term than the considered six-year period. Future researchers are hence encouraged to consider a longer study period when investigating relationships between ESG and CFP.

It should be noted that the considered ESG disclosure scores might not necessarily reflect the true ESG practices of firms. These scores were primarily based on corporate reporting. Even though firms are required to disclose both positive and negative aspects, it is debatable whether they will do so, given the repercussions that this might have on their business. Greater effort should thus be made to properly disclose a firm's actual ESG performance. Attention should also be given to whether the currently employed measures accurately reflect the different dimensions of ESG performance. Future researchers should contemplate alternative ways to measure a firm's actual ESG performance.

It is essential that stakeholders, such as shareholders, suppliers and customers, should 'come on board' by acknowledging that ESG aspects should be considered and accounted for over the long run to create value in a 
sustainable manner. By focusing on sustainable financial and ESG returns, companies, and investors, can do well by doing good.

\section{Acknowledgements}

Thank you to Prof. Kidd for assisting with the statistical analysis and Dr Albertyn for serving as a critical reader.

\section{Competing interests}

The authors have declared that no competing interest exist.

\section{Authors' contributions}

R.J. conducted this study in pursuit of her master's degree. N.M-K. and P.D.E. were the supervisors. All authors contributed to the writing of this article.

\section{Funding information}

This research received no specific grant from any funding agency in the public, commercial, or not-for-profit sectors.

\section{Data availability statement}

Data sharing is not applicable to this article as no new data were created or analysed in this study.

\section{Disclaimer}

The views and opinions expressed in this article are those of the authors and do not necessarily reflect the official policy or position of any affiliated agency of the authors.

\section{References}

Aaltonen, A., 2013, Environmental, social and corporate governance practices in the MENA region 2007-2012, viewed 25 June 2017, from http://hawkamah.org/ wpcontent/uploads/2014/10/environmental.social.and_corporategovernance. practices.in_.the_.MENA_.region.2007-2012.pdf.

Aguilera, R.V., Filatotchev, I., Gospel, H. \& Jackson, G., 2008, 'An organizational approach to comparative corporate governance: Costs, contingencies, and complementarities', Organization Science 19(3), 475-492. https://doi.org/10.1287/orsc.1070.0322

Ameer, R. \& Othman, R., 2012, 'Sustainability practices and corporate financial performance: A study based on the top global corporations', Journal of Business Ethics 108(1), 61-79. https://doi.org/10.1007/s10551-011-1063-y

Atkins, J. \& Maroun, W., 2012, 'Integrated reporting in South Africa in 2012', Meditar Accountancy Research 23(2), 197-221. https://doi.org/10.1108/MEDAR-07-2014-0047

Balatbat, M., Siew, R.Y.J. \& Carmichael, D.G., 2012, ESG scores and its influence on firm performance: Australian evidence, viewed 17 May 2018, from https://www. researchgate.net/publication/260907931_ESG_Scores_and_its_Influence_on firm_performance_Australian_Evidence/download.

Bassen, A. \& Kovács, A.M., 2008, 'Environmental, social and governance key performance indicators from a capital market perspective', Zeitschrifür Wirtschas und Unternehmensethik 9(2), 182-192.

Bauer, R., Guenster, N. \& Otten, R., 2004, 'Empirical evidence on corporate governance in Europe: The effect on stock returns, firm value and performance', Journal of Asset Management 5(2), 91-104. https://doi. org/10.1057/palgrave.jam.2240131

Bloomberg, L.P., 2017, ESG disclosure scores, Research domain, Software and database, New York.

Brammer, S., Brooks, C. \& Pavelin, S., 2006, 'Corporate social performance and stock returns: UK evidence from disaggregate measures', Financial Management 35(3), 97-116.

Breuer, N. \& Nau, C., 2014, 'ESG performance and corporate financial performance An empirical study of the US technology sector', Master's thesis, Department of Business Administration, Lund University.

Brigham, E.F. \& Daves, P.R., 2010, Intermediate financial management, South-Western Cengage Learning, Cincinnati, $\mathrm{OH}$.
Callan, S.J. \& Thomas, J.M., 2009, 'Corporate financial performance and corporate social performance: An update and reinvestigation', Corporate Social Responsibility and Environmental Management 16(2), 61-78. https://doi. Responsibility and
$\mathrm{org} / 10.1002 / \mathrm{csr} .182$

Carroll, A.B., 1999, 'Corporate social responsibility', Business and Society 38(3), 268295. https://doi.org/10.1177/000765039903800303

Carroll, A.B. \& Shabana, K.M., 2010, 'The business case for corporate social responsibility: A review of concepts, research and practice', International Journal of Management Reviews 12(1), 85-105. https://doi.org/10.1111/j.1468-2370.2009.00275.x

Chetty, S., Naidoo, R. \& Seetharam, Y., 2015, 'The impact of corporate social responsibility on firms' financial performance in South Africa', Contemporary Economics 9(2), 193-214.

Cooper, S., 2017, Corporate Social Performance: A stakeholder approach, Routledge, Oxon.

Dahlsrud, A., 2008, 'How corporate social responsibility is defined: An analysis of 37 definitions', Corporate Social Responsibility and Environmental Management 15(1), 1-13. https://doi.org/10.1002/csr.132

De Klerk, M. \& De Villiers, C., 2012, 'The value relevance of corporate responsibility reporting: South African evidence', Meditari Accountancy Research 20(1), 21-38. https://doi.org/10.1108/10222521211234200

Demetriades, K. \& Auret, C.J., 2014, 'Corporate social responsibility and firm performance in South Africa', South African Journal of Business Management 45(1), 1-12. https://doi.org/10.4102/sajbm.v45i1.113

Du Toit, E. \& Lekoloane, K., 2018, 'Corporate social responsibility and financial performance: Evidence from the Johannesburg Stock Exchange, South Africa', South African Journal of Economic and Management Sciences 21(1), a1799. https://doi.org/10.4102/sajems.v21i1.1799

Eccles, N.S., De Jongh, D., Nicholls, S.J., Sinclair, G. \& Walker, P., 2007, The state of responsible investment in South Africa: A survey of the approaches and perceptions responsible investment in South Africa: A survey of the approaches and perceptions
of the South African investment community to environmental, social and governance issues, viewed 14 February 2018, from https://www.unepfi.org/ governance issues, viewed 14 February 2018, from https://Www.
fileadmin/documents/The_State_of_Responsible_Investment_01.pdf.

Els, G., Erasmus, P.D. \& Viviers, S., 2014, Corporate finance: A South African perspective, Cape Town, Oxford University Press.

Equator Principles, 2018, Equator principles association members \& reporting, viewed 04 May 2018, from https://equator-principles.com/members-reporting/.

Erasmus, P.D., 2008, 'The relative and incremental information content of the valuebased financial performance measure cash value added (CVA)', Management Dynamics 17(1), 2-15.

Ferrero-Ferrero, I., Fernández-Izquierdo, M.A. \& Muñoz-Torres, M.J., 2016, 'The effect of environmental, social and corporate governance consistency on economic results', Sustainability 8(10), 1005-1021. https://doi.org/10.3390/su8101005

Ford Motor Company, 2010, Sustainability report 2010, viewed 23 January 2018, from https://issuu.com/autokiosk/docs/2010_ford_sustainability_report_2009-2010.

Friede, G., Busch, T. \& Bassen, A., 2015, 'ESG and financial performance: Aggregated evidence from more than 2000 empirical studies', Journal of Sustainable Finance and Investment 5(4), 210-233. https://doi.org/10.1080/20430795.2015.1118917

Galema, R., Plantinga, A. \& Scholtens, B., 2008, 'The stocks at stake: Return and risk in
socially responsible investing', Journal of Banking and Finance 32(12), 2646-2654. socially responsible investing', Journal of Banking and Finance 32(12), 2646-2654
https://doi.org/10.1016/j.jbankfin.2008.06.002

Gentry, R.J. \& Shen, W., 2010, 'The relationship between accounting and market measures of firm financial performance: How strong is it?', Journal of Management Issues 22(4), 514-530. https://doi.org/10.2307/25822528

Girdwood, A., 2013, 'Responsible investment for pension fund trustees: A work in progress?' World Wide Fund for Nature South Africa, viewed 23 February 2018,
from http://awsassets.wwf.org.za/downloads/responsible_investment_for prom http://awsassets.wwf.org.za/downloads/responsib_trund_trustees_briefing_paper_july_2013.pdf.

Gladysek, O. \& Chipeta, C., 2012, 'The impact of socially responsible investment index constituent announcements on firm price: Evidence from the JSE', South African Journal of Economic and Management Sciences 15(4), 429-439. https://doi. org/10.4102/sajems.v15i4.236

Gond, J.P., O'Sullivan, N., Slager, R., Homanen, M., Viehs, M. \& Mosony, S., 2018, 'How ESG engagement creates value for investors and companies', United Nations Principles for Responsible Investing, viewed 04 April 2019, from https://www. unpri.org/download? $\mathrm{ac}=4637$.

Hebb, T., Hawley, J.P., Hoepner, A.G.F., Neher, A.L. \& Wood, D., 2016, The Routledge handbook of responsible investment, Routledge, Oxon.

Herringer, A., Firer, C. \& Viviers, S., 2009, 'Key challenges facing the socially responsible investment (SRI) sector in South Africa', Investment Analysts Journal 70(2), 11-26. https://doi.org/10.1080/10293523.2009.11082511

Horn, R., De Klerk, M. \& De Villiers, C., 2018, 'The association between corporate social responsibility reporting and firm value for South African firms', South African Journal of Economic and
org/10.4102/sajems.v21i1.2236.

Hörnmark, P., 2015, 'Responsible investment: Should investors incorporate ESG principles when investing in emerging markets?', Master's thesis, Jönköping International Business School, Jönköping University.

Institute of Directors in Southern Africa (IoDSA), 2011, Code for responsible investing in South Africa, IoDSA, Johannesburg.

Institute of Directors in Southern Africa (IoDSA), 2016, King IV report on corporate governance for South Africa-2016, IODSA, Johannesburg.

Integrated Reporting Committee (IRC) of South Africa, 2018, The international framework, viewed 12 May 2018, from http://integratedreportingsa.org/ircsa/ wp-content/uploads/2017/05/13-12-08-THE-INTERNATIONAL-IRFRAMEWORK-2-1.pdf. 
IRESS, 2017, Research Domain, Software and Database, Johannesburg.

Limkriangkrai, M., Koh, S. \& Durand, R.B., 2017, 'Environmental, social, and governance (ESG) profiles, stock returns, and financial policy: Australian evidence', International Review of Finance 17(3), 461-471. https://doi.org/10.1111/irfi.12101

Linnenluecke, M.K. \& Griffiths, A., 2010, 'Corporate sustainability and organizational culture', Journal of World Business 45(4), 357-366. https://doi.org/10.1016/j. jwb.2009.08.006

Lins, K.V., Servaes, H. \& Tamayo, A., 2017, 'Social capital, trust, and firm performance: The value of corporate social responsibility during the financial crisis', The Journa of Finance $72(4), 1785-1824$. https://doi.org/10.1111/jofi.12505

Maditinos, D., Šević, Z. \& Theriou, N., 2006, 'A review of the empirical literature on earnings and economic value added (EVA ${ }^{\circledR}$ ) in explaining stock market returns. Which performance measure is more value relevant in the Athens Stock Exchange (ASE)?', Fifth Annual Conference of the Hellenic Finance and Accounting Association, Thessaloniki, 15-16 December 2006, viewed 22 June 2018, from http://abd.teikav.edu.gr/articles/Review.pdf.

Mangena, M. \& Chamisa, E., 2008, 'Corporate governance and incidences of listing suspension by the JSE Securities Exchange of South Africa: An empirical analysis', The International Journal of Accounting 43(1), 28-44. https://doi.org/10.1016/j. intacc.2008.01.002

Mans-Kemp, N., Erasmus, P.D. \& Viviers, S., 2017, 'Does investing in sound corporate governance pay? A South African study', South African Journal of Business Management 48(2), 33-43. https://doi.org/10.4102/sajbm.v48i2.26

Marcia, A., Maroun, W. \& Callaghan, C., 2015, 'Value relevance and corporate responsibility reporting in the South African context: An alternate view post KingIII', South African Journal of Economic and Management Sciences 18(4), 500-518. https://doi.org/10.4102/sajems.v18i4.1192

Marco, M., 2011, 'Accountability in international project finance: The Equator Principles and the creation of third-party beneficiary status for project-affected communities', Fordham International Law Journal 34(3), 452-503.

Margolis, J.D. \& Walsh, J.P., 2001, People and profits? The search for a link between a company's social and financial performance, Psychology Press, New York.

Martin, J.D., Petty, J.W. \& Wallace, J.S., 2009, Value-based management with corporate social responsibility, Oxford University Press, New York.

Masa'deh, R., Tayeh, M., Jarrah, I. \& Tarhini, A., 2015, 'Accounting vs. market-based measures of firm performance related to information technology investments', International Review of Social Sciences and Humanities 9(1), 129-145.

Matten, D. \& Moon, J., 2008, "Implicit" and "explicit" CSR: A conceptual framework for a comparative understanding of corporate social responsibility', The Academy of Management Review 33(2), 404-424.

Megginson, W.L., Smart, S.B. \& Graham, J.R., 2010, Financial management, SouthWestern Cengage Learning, Cincinnati, $\mathrm{OH}$.

Michelon, G., Boesso, G. \& Kumar, K., 2013, 'Examining the link between strategic corporate social responsibility and company performance: An analysis of the best corporate citizens', Corporate Social Responsibility and Environmental Management 20(2), 81-94. https://doi.org/10.1002/csr.1278

Mutezo, A., 2014, 'Socially responsible investment and financial performance: Evidence from the Johannesburg Securities Exchange', Banks and Bank Systems 9(3), 120-128.

Nkomani, S., 2013, 'Corporate social responsibility and financial performance: The Johannesburg Stock Exchange Top 100', Master's thesis, University of Pretoria.

Nollet, J., Filis, G. \& Mitrokostas, E., 2016, 'Corporate social responsibility and financial performance: A non-linear and disaggregated approach', Economic Modelling 52(part B), 400-407. https://doi.org/10.1016/j.econmod.2015.09.019

Ntim, C.G., Opong, K.K., Danbolt, J. \& Thomas, D.A., 2012, 'Voluntary corporate governance disclosures by post-apartheid South African corporations', Journal of Applied Accounting Research 13(2), 122-144. https://doi.org/10.1108/09675421211254830

Orlitzky, M., Schmidt, F.L. \& Rynes, S.L., 2003, 'Corporate social and financial performance: A meta-analysis', Organisation Studies 24(3), 403-441. https://doi. org/10.1177/0170840603024003910

Pasquini-Descomps, H. \& Sahut, J.M., 2013, ESG impact on a firm's performance in Switzerland, viewed 23 June 2018, from https://www.researchgate.net/ publication/248392697_ESG_Impact_on_a_Firm's_Performance_in_Switzerland.

Porter, G.A. \& Norton, C.L., 2016, Financial accounting: The impact on decisionmakers, Cengage Learning, Boston, MA.
Qiu, Y., Shaukat, A. \& Tharyan, R., 2016, 'Environmental and social disclosures: Link with corporate financial performance', The British Accounting Review 48(1), 102-116. https://doi.org/10.1016/j.bar.2014.10.007

Quinn, L. \& Baltes, J., 2007, 'Leadership and the triple bottom line, bringing sustainability and corporate social responsibility to life', Centre for Creative Leadership Research White Paper, viewed 23 June 2018, from http://admin.csrwire.com/system/report pdfs/522/original/1205941758_tripleBottomLine.pdf.

Revelli, C. \& Viviani, J-L., 2015, 'Financial performance of socially responsible investing (SRI): What have we learned? A meta-analysis', Business Ethics: A European Review 24(2), 158-185. https://doi.org/10.1111/beer.12076

Richardson, A.J. \& Welker, M., 2001, 'Social disclosure, financial disclosure and the cost of equity capital', Accounting, Organisations and Society 26(7), 597-616. https://doi.org/10.1016/S0361-3682(01)00025-3

Rodriguez-Fernandez, M., 2016, 'Social responsibility and financial performance: The role of good corporate governance', BRQ Business Research Quarterly 19(2), 137-151. https://doi.org/10.1016/j.brq.2015.08.001

Simpson, W.G. \& Kohers, T., 2002, 'The link between corporate social and financial performance: Evidence from the Banking industry', Journal of Business Ethics 35(2), 97-109. https://doi.org/10.1023/A:1013082525900

Sustainable Investment Research Analyst Network, 2009, A review of ESG practices in large emerging market companies, viewed 25 April 2018, from https://ecodes. org/docs/Emerging_Markets_Paper.pdf.

Tshipa, J., Brummer, L.M., Wolmarans, H. \& Du Toit, E., 2018, 'The effect of industry nuances on the relationship between corporate governance and financial nuances on the relationship between corporate governance and financial
performance: Evidence from South African listed companies', South African performance: Evidence from South African listed companies, South African Journal of Economic

Van De Velde, E., Vermeir, W. \& Corten, F., 2005, 'Corporate social responsibility and financial performance', Corporate Governance: The International Journal of financial performance', Corporate
Business in Society 5(3), 129-138.

Van Der Ahee, G. \& Schulschenk, J., 2013, The state of responsible investing in South Africa, viewed 17 April 2018, from http://www.ey.com/Publication/vwLUAssets/ Africa, viewed 17 April 2018, from http://www.ey.com/Publication/vwLUAssets/ TheStateof_Responsible_Investment
Investment $\% 20$ Study\%202013.pdf.

Van Der Laan, G., Van Ees, H. \& Van Wittelosstuijn, A., 2008, 'Corporate social and financial performance: An extended stakeholder theory, and empirical test with accounting measures', Journal of Business Ethics 79(3), 299-300. https://doi. accounting measures', Journal of
org/10.1007/s10551-007-9398-0

Velnampy, T. \& Pratheepkanth, P., 2013, 'Corporate governance and firm performance: A study of selected listed companies in Sri Lanka', European Journal of Commerce and Management Research 2(6), 123-127.

Venanzi, D., 2012, Financial performance measures and value creation: The state of the art, Springer-Verlag, Milan.

Viviers, S., Bosch, J.K., Smit, E.v.d.M. \& Buijs, A., 2008, 'The risk-adjusted performance of responsible investment funds in South Africa', Investment Analysts Journal 37(68), 39-52. https://doi.org/10.1080/10293523.2008.11082503

Viviers, S., Bosch, J.K., Smit, E.v.d.M. \& Buijs, A., 2009, 'Responsible investing in South Africa', Investment Analysts Journal 38(69), 3-16. https://doi.org/10.1080/10293 523.2009.11082505

Viviers, S., Krüger, J. \& Venter, D.J.L., 2012, 'The relative importance of ethics, environmental, social and governance criteria', African Journal of Business Ethics 6(2), 120-132. https://doi.org/10.15249/6-2-29

Viviers, S. \& Smit, E.v.d.M., 2015, 'Institutional proxy voting in South Africa: Process, outcomes and impact', South African Journal of Business Management 46(4), 23-34.

Waddock, S.A. \& Graves, S.B., 1997, 'The corporate social performance - Financial performance link', Strategic Management Journal 18(4), 303-319.

Waweru, N.M., 2014, 'Determinants of quality corporate governance in sub-Saharan Africa: Evidence from Kenya and South Africa', Managerial Auditing Journal 29(5), 455-485. https://doi.org/10.1108/MAJ-07-2013-0897

Werbach, A., 2009, Strategy for sustainability: A business manifesto, Harvard, Boston, $\mathrm{MA}$.

World Economic Forum, 2017, The global competitiveness report 2017-2018, viewed 11 October 2017, from http://www3.weforum.org/docs/GCR2017-2018/05FullReport/ TheGlobalCompetitivenessReport2017\%E2\%80\%932018.pdf 